\title{
透析患者の冠動脈造影とインターベンション治療： 基礎疾患に関する検討
}

\author{
杉本 徳一郎 大本由 樹* 多川斉齋藤肇 \\ 長田太助原和 弘* 田村 勤* \\ 三井記念病院内科腎センター 同循環器センター*
}

key words：虚血性心疾患, 冠動脈造影, 冠動脈バイパス手術, PTCA, 血液透析患者

〈要旨〉

1995 年 3 月までに, 冠動脈造影を施行した透析患者 143 例のうち, 冠動脈に有意狭窄を有した患者は 108 例, 有 意狭窄病変のない 0 枝病変の患者は 35 例であった. 有意狭窄病变を有する患者の基礎疾患は, 慢性腎炎 $33 \%$, 糖尿 病性腎症 42\%, 腎硬化症 17\%, 乥の他 $7 \%$ であり, 透析患者一般に比べて糖尿病性腎症と腎硬化症の頻度が高かっ た。腎硬化症の患者は, 慢性腎炎, 糖尿病性腎症の患者より高齢であった。透析期間は, 慢性腎炎の 6.1 年に比べ て, 糖尿病性腎症では 2.3 年, 腎硬化症では 1.3 年と有意に短かった。すなわち糖尿病性腎症および腎硬化症によ る透析患者は虚血性心疾患を合併する頻度が高く, 透析導入期にすでに有意狭窄を合併する症例が多いことが示さ れた。 また糖尿病性腎症と腎硬化症では， 3 枝病変や左冠動脈主幹部病変などの高度病変が多い傾向がみられた。 有意狭窄病変を有する患者に対して，原則として $1 \sim 2$ 枝病変にはPTCA を，3枝または左冠動脈病変には CABG を選択した. しかし, 冠動脈石灰化や動脈硬化性合併症などのため, やむを得ず薬物療法を選択する症例もあった。

\section{Coronary angiography and revascularization in chronic dialysis patients: Analysis of the causes of end-stage renal disease}

Tokuichiro Sugimoto, Yuki Ohmoto*, Hitoshi Tagawa, Hajime Saito, Daisuke Nagata, Kazuhiro Hara*, Tsutomu Tamura*

Division of Nephrology and Cardiovascular Center*, Department of Medicine, Mitsui Memorial Hospital

Significant coronary stenosis was detected in 108 of 143 dialysis patients who underwent coronary angiography in our institution to March of 1995. In the patients with significant coronary stenosis $(n=108)$, the main causes of end-stage renal disease were chronic glomerulo nephritis (CGN ; 33\%), diabetic nephropathy (DN ; $42 \%$ ), and nephrosclerosis (NSC ; 17\%). DN and NSC were more prevalent than CGN compared to end-stage renal disease (ESRD) patients in general. The mean age was higher in patients with NSC than in other patients. The duration of dialysis was significantly shorter in DN (2.3 \pm 3.3 years, $m \pm S D)$ and in NSC (1.3 \pm 1.7$)$ than

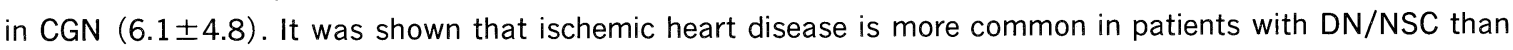
in patients with CGN. Patients with DN/NSC were frequently complicated with ischemic heart disease when dialysis was initiated and they tended to have severe coronary lesions. We usually applied percutaneous transluminal coronary angioplasty (PTCA) in patients with 1 or 2-vessel diseases and coronary artery bypass grafting $(C A B G)$ in patients with 3-vessel diseases or the left main trunk lesions, however the intervensive treatment was not performed in some patients because of severe coronary calcification or atherosclerotic complication.

杉本徳一郎 三井記念病院内科腎センター $\quad$ 个 101 千代田区神田和泉町 1 (03-3862-9111)

〔受付：平成 8 年 1 月 8 日, 受理 : 平成 8 年 3 月 21 日〕 
表 1 有意狭窄病変を有する患者の年齢と透析期間

\begin{tabular}{|c|c|c|c|c|c|}
\hline 基礎疾患 & 例数（\%） & $\#$ & 男：女 & 年齢（歳） & 透析期間（年） \\
\hline 慢性腎炎 & $36 \quad(33)$ & $40.5 \%$ & $32: 4$ & $56.7 \pm 9.8 \square$ & $6.1 \pm 4.8 \overline{7_{*}}$ \\
\hline 糖尿病性腎症 & $45 \quad(42)$ & $30.7 \%$ & $33: 12$ & $60.1 \pm 6.8\urcorner^{*}$ & $2.3 \pm 3.3 \stackrel{*}{*}_{*}$ \\
\hline 腎硬化症 & $18 \quad(17)$ & $6.1 \%$ & $15: 3$ & $68.1 \pm 5.1 \stackrel{*}{=}$ & $1.3 \pm 1.7-$ \\
\hline その他 & $9(7)$ & - & $7: 2$ & - & - \\
\hline
\end{tabular}

\section{緒言}

近年透析患者の高齢化と糖尿病性腎症による腎 不全患者の増加に伴って, 透析患者の管理にあ たって虚血性心疾患が重要視されるようになっ た ${ }^{1 \sim 3)}$. 我々は, 1980 年以降透析患者の虚血性心疾 患について冠動脈造影とインターベンション治療 を施行してきた.ここでは，透析患者の虚血性心 疾患の特質を明らかにするために，これらの成績 について基礎疾患を中心に検討した。

\section{対象・方法}

対象は, 1995 年 3 月までに三井記念病院に入院 -し，狭心症および心電図変化から，あるいは心機 能低下と心電図所見から虚血性心疾患が疑われて 冠動脈造影を施行した導入期および維持期透析患 者 143 例（男 108 例，女 35 例）である。透析導入 前にインターベンション治療を受けた患者は除外 した.インターベンション治療として, 経皮的冠 動脈形成術 (percutaneous transluminal coronary angioplasty；PTCA） カッターによる冠動 脈粥腫切除術 (directional coronary atherectomy；DCA)，ステント留置術（stent）または 冠動脈バイパス手術（coronary artery bypass grafting；CABG）を施行した。造影検査を複数 回施行した患者については, 初回施行時の成績に 限った。これらの基礎疾患, 年歯令, 診断までの透 析期間, 冠動脈有意狭窄病変の枝数, 選択した治 療法の種類について調査した。

\section{結果}

対象 143 例のうち, 冠動脈に 75\%以上の有意狭 窄病変を有した患者は 108 例 (男/女 $=87 / 21$ ), 有 意狭窄病変のない 0 枝病変の患者は 35 例（男/ 女=21/14）であった。

有意狭窄病変を有する患者における腎不全の基 礎疾患（表 1）は，慢性腎炎 $33 \% ，$ 糖尿病性腎症
表 2 基礎疾患と病変枝数

\begin{tabular}{|c|c|c|c|c|c|c|c|c|}
\hline & $\mathrm{n}$ & & 1 枝 & & 2 枝 & & 3 枝 & LMT \\
\hline 慢性腎炎 & 36 & 10 & $(28 \%)$ & 15 & $(42 \%)$ & 9 & $(25 \%)$ & $2(6 \%)$ \\
\hline 糖尿病性腎症 & 45 & 13 & $(29 \%)$ & 15 & $(33 \%)$ & 13 & $(29 \%)$ & $4(9 \%)$ \\
\hline 腎硬化症 & 18 & 6 & $(33 \%)$ & 5 & $(28 \%)$ & 5 & $(28 \%)$ & $2(11 \%)$ \\
\hline その他 & 9 & 1 & $(11 \%)$ & 4 & $(44 \%)$ & 4 & $(44 \%)$ & $0(0 \%)$ \\
\hline \multicolumn{8}{|c|}{$\mathrm{LMT}=$ 左冠動脈主幹部病変 } & $\begin{aligned} \chi^{2} & =1.52 \\
\mathrm{p} & =0.95\end{aligned}$ \\
\hline
\end{tabular}

$42 \%$, 腎硬化症 $17 \%$, その他 $7 \%$ であり, 糖尿病 性腎症患者が最も多かった。日本透析医学会によ る全国集計の導入患者の原疾患 ${ }^{1)}$ に比べて, 糖尿 病性腎症と腎硬化症の頻度が明らかに高值であっ た. 年歯は, 腎硬化症において他の 2 群より有意 に高齢であった.平均透析期間は, 慢性腎炎の 6.1 年に比べて, 糖尿病性腎症では 2.3 年, 腎硬化症 では 1.3 年と有意に短く, 透析導入時にすでに虚 血性心疾患が合併している症例が多いことが示さ れた. 男女別の疾患背景についてみると, 有意狭 窄を有する女性患者のうちで糖尿病患者の比率が 高いことが示された $(12 / 21$ 例).

有意狭窄病変を有する患者において，基礎疾患 別に病変枝数を分析した (表 2$)$. 糖尿病性腎症と 腎硬化症では，3枝病変と左冠動脈主幹部病変な どの高度病変が多い傾向がみられたが，有意差は なかった。

有意狭窄病変を有する患者の治療法について, 病変枝数別に検討した (表 3 ) 。有意狭窄病変に対 する我々のインターベンション治療の方針は狭窄 病変の形態と社会適応によって判断した。原則と して，1〜2枝病変例に対してはPTCA，3 枝病 変ないし左冠動脈主幹部病変に対しては $\mathrm{CABG}$ としており，透析患者においても概ね原則に準じ ていた。しかし，1枝でも PTCA 後に CABGを 施行した例や， 3 枝病変でも PTCA を選択した 
表 3 治療法別の病変枝数

\begin{tabular}{lrrrrc}
\hline & $\mathrm{n}$ & \multicolumn{1}{c}{1 枝 } & \multicolumn{1}{c}{2 枝 } & \multicolumn{1}{c}{3 枝 } & LMT \\
\hline 薬物治療のみ & 21 & $7(33 \%)$ & $8(38 \%)$ & $5(24 \%)$ & $1(5 \%)$ \\
PTCA & 46 & $19(41 \%)$ & $21(46 \%)$ & $6(13 \%)$ & $0(0 \%)$ \\
CABG & 24 & $0(0 \%)$ & $5(21 \%)$ & $14(58 \%)$ & $5(21 \%)$ \\
PTCA +CABG & 14 & $1(7 \%)$ & $4(29 \%)$ & $7(50 \%)$ & $2(14 \%)$ \\
CABG+弁置換 & 3 & $3(100 \%)$ & 0 & 0 & 0 \\
\hline \multicolumn{1}{c}{$\quad$ 計 } & 108 & $30(28 \%)$ & $38(35 \%)$ & $32(30 \%)$ & $8(7 \%)$ \\
\hline
\end{tabular}

例もあった. PTCA 46.例には, DCA 5 例と stent が 3 例含まれている. DCA は偏心性の狭窄に対 して, stent は石死化が強く PTCA が困難と思わ れる病変に対して施行した. DCA 5 例中 2 例は 初回インターベンション治療において施行し, 他 の DCA および stent の症例は PTCA 後あるい は $\mathrm{CABG}$ 後の再狭窄病変に対して施行した。 $\mathrm{PTCA}+\mathrm{CABG}$ とした 14 例は経過中単一の治療 法では不十分で両者の併施を必要とした例であ る. PTCA 後に CABG を要した患者が 9 例であ り, このうち PTCA 不成功のため CABG へ移 行した患者は 4 例であった. 一方 CABG 後に, 狭窄に対して PTCA が施行されたのが 5 例で あった。また, 有意狭窄病変がありながら, 病変 の性質, 全身状態や合併症のため, PTCA や $\mathrm{CABG}$ が困難と考えられ, 薬物治療のみとした患 者が 21 例であった。

次に, 治療法について基礎疾患別に検討した（表 4 ). 糖尿病性腎症では, 薬物療法のみは $29 \%$ であ り，慢性腎炎 (17\%) や腎硬化症（6\%）より高 率であった。また, 糖尿病性腎症では, インター ベンション治療は CABG が選択される頻度が他 群よりも高い傾向がみられた。

PTCA と CABG の初回施行例 (それぞれ 48 例 と 28 例) について, 短期的な治療成績を検討した。 ここでは待機的治療例のみに限定し，応急治療例 は除外した。PTCA は患者成功率 88\% (42/48 例), 病変成功率 $88 \%(71 / 81$ 病変 $)$ であった。病 変不成功 (10 病変) の原因はガイドワイヤー不通 過 7 病変, バルーン不通過 1 病変, $\mathrm{Q}$ 波梗塞 2 病 変であった。 3 か月後の再造影例では, 病変再狭 窄は $40 \%$ にいてて観察された。病変不成功, 再狭 窄について, 基礎疾患による差は認められなかっ
表 4 治療法別の基礎疾患

\begin{tabular}{crrcrc}
\hline & $\mathrm{n}$ & $\begin{array}{c}\text { 慢性 } \\
\text { 腎炎 }\end{array}$ & $\begin{array}{c}\text { 糖尿病性 } \\
\text { 腎症 }\end{array}$ & $\begin{array}{c}\text { 腎硬 } \\
\text { 化症 }\end{array}$ & その他 \\
\hline 薬物治療のみ & 21 & 6 & 13 & 1 & 1 \\
PTCA & 46 & 17 & 16 & 10 & 3 \\
CABG & 24 & 6 & 11 & 4 & 3 \\
PTCA+CABG & 14 & 5 & 4 & 3 & 2 \\
CABG+弁置換 & 3 & 2 & 1 & 0 & 0 \\
\hline & 108 & 36 & 45 & 18 & 9 \\
\hline
\end{tabular}

た. CABG は生存退院は $82 \%$ (23/28 例) であっ た. 術後の院内死亡は, 消化管出血や感染症が 4 例であり，心臓死は 1 例のみであった。

0 枝病変例は, 冠動脈径の部分的な不整を認め るが $75 \%$ 未満の狭窄であった 8 例（慢性腎炎 2 例, 糖尿病性腎症 4 例, 腎硬化症 1 例）と, 一見 して径不整が認められない normal coronary と いうべき 27 例（慢性腎炎 17 例, 糖尿病性腎症 5 例，腎硬化症 1 例）を含んでいた。

normal coronary 例は, 貧血 (Hb 6.2 7.0 g/ $\mathrm{d} l)$ のため負荷心電図が陽性を示した例, 心機能 低下と著明な心電図変化があった拡張型心筋症 (dilated cardiomyopathy) と診断された例, 高度 の大動脈弁膜症を認めた例, 著しい左室肥大によ り心電図 ST 変化の強かった例などであった。

\section{考案}

冠動脈に有意狭窄病変を有する透析患者の基礎 疾患は, 日本透析医学会による全国集計 ${ }^{1)}$ の透析 導入患者に比べて, 糖尿病性腎症と腎硬化症の占 める比率が慢性腎炎よりも高いことが示された。 同学会による 1994 年末現在の維持透析患者の基 礎疾患は慢性腎炎 $57.7 \%$, 糖尿病性腎症 $19.2 \%$, 腎硬化症 $3.6 \%$ であり ${ }^{1)}$, これに比べると, 我々の 対象例における糖尿病性腎症と腎硬化症の比率は 
さらに高かった，有意狭窄病変の診断までの平均 透析期間は糖尿病性腎症では 2.3 年, 腎硬化症で は 1.3 年であり, 慢性腎炎の 6.1 年に比べて有意 に短かった。糖尿病性腎症においては糖尿病自体 が動脈硬化の促進因子であること，腎硬化症にお いては導入時の年齢が高齢であることから，透析 導入時にすでに冠動脈硬化が進行しているものと 考えられる.また, 糖尿病性腎症と腎硬化症では, 3 枝病変と左冠動脈主幹部病変などの高度病変が 多い傾向がみられた．近年透析導入患者における 糖尿病性腎症の比率が年々増加しており ${ }^{1)}$, 今後 透析導入期の重症の虚血性心疾患が問題となって くるものと予測される.

有意狭窄病変を有する患者のインターベンショ ン治療について，我々は，原則として $1 \sim 2$ 枝病 変には PTCA を， 3 枝または左冠動脈主幹部病 変には CABG を選択した。しかし, 糖尿病患者 においては，脳血管病変や閉塞性動脈硬化症のた め PTCA や CABG を施行し得ない例, あるい は高度の石灰化や long segment の強い狭窄例に 対して，やむを得ず薬物療法を選択することが多 い.インターベンション治療の短期的な安全性や 有効率は透析患者においても良好であるが，長期 成績については今後詳細に検討する必要がある.

従来, 透析患者の冠動脈疾患の特徵として動脈 壁の石灰化があげられている ${ }^{3 \sim 6)}$. 石灰化は透析導 入直後の患者にも認められるが，高度な石灰化は 長期透析患者に多く ${ }^{4)}$, 透析歴 8 年以上の患者で は検査した全例に認められるという3). 石灰化の 程度と有意狭窄病変数は関連がなく5), この石灰 化の部位は, 冠動脈狭窄の本質である内皮下の肥 厚病変（プラーク）とは必ずしも一致するもので はないがX線透視下に高度の石灰化が認められる 時は, 狭窄病変も強くかつ長い場合が多く, PTCA の不成功や再狭窄の強いリスクと考元られて る ${ }^{3,7)}$. 我々は, 石灰化を伴う病変は, 複数回の PTCA や一部はステントや DCA などの new device による治療を施行した. 石灰化を伴う狭窄 病変の治療の選択については今後検討を要する課 題である. 近年, 血管内エコー法 (intravascular ultrasound imaging）により，動脈内膜の石灰化
が X線透視よりも高感度に検出されるようになっ たが8), 透析患者における冠動脈石灰化病変につ いても本法の利用が期待される.

透析患者の高齢化, 糖尿病性腎症による腎不全 患者の増加に伴って, 虚血性心疾患の治療は透析 医療において重要視されるようになった。透析導 入初期から冠動脈狭窄を有する症例も少なくない ことを考慮して虚血性心疾患を速やかに発見し適 切に治療することは, 安定した透析導入と維持透 析の継続のために極めて大切である.

\section{文献}

1）日本透析医学会統計調查委員会：わが国の慢性 透析療法の現状 (1994 年 12 月 31 日現在). 透析 会誌 29：1-22，1996

2）永野正史, 多川 斉, 山口 徹：透析患者の虚 血性心疾患. 日本臨牀 50 (増刊 血液浄化法下 巻) : 684-689, 1992

3）一色高明, 山口 徹, 多川 斉：慢性透析患者 における冠動脈造影所見とその適応. 透析会誌 26:111-113, 1993

4）多川 斉，樫田光夫，山門 実：長期透析患者 にみられる冠動脈のびまん性石扊化とその冠動 脈造影所見. 透析 (16), 人工透析研究会編, p 57-60, 1984

5）宇都宮正範, 太田 真, 佐藤成明, 田中 博, 重松 隆, 杉本健一, 田中忠司, 小野益照, 斎 藤広重, 岡田秀雄, 川口良人: 維持透析患者に おける冠動脈病変と石死化の検討(第 1 報). 透 析会誌 $27 ： 1411-1416,1994$

6）中西浩次，金子哲也，矢野文雄，堀尾 勝，陳 若富, 安村良男, 林亨, 松浦泰彦, 福島正 勝, 福原吉典 : 透析患者の虚血性心疾患. 透析 会誌 $25 ： 1225-1230,1992$

7) Takeshita S, Isshiki T, Tagawa H, Yamaguchi $\mathrm{T}$ : Transluminal coronary angioplasty for chronic dialysis patients. J Invas Cardiol $5: 345-350,1993$

8) Mintz GS, Douek P, Pichard AD, Kent KM, Satler LF, Popma JJ, Leon MB: Target lesion calcification in coronary artery disease: an intravascular ultrasound study. J Am Coll Cardiol 20 : 1149-1155, 1992 